ZOOLOGIA 28 (6): 709-716, December, 2011

doi: $10.1590 /$ S1984-46702011000600003

\title{
Small mammals in the diet of Barn owls, Tyto alba (Aves: Strigiformes) along the mid-Araguaia River in central Brazil
}

\author{
Rita G. Rocha ${ }^{1,2,3}$; Eduardo Ferreira'; Yuri L.R. Leite'; Carlos Fonseca' \& Leonora P. Costa² \\ ${ }^{1}$ Departamento de Biologia, Universidade de Aveiro. Campus de Santiago, 3810-193, Aveiro, Portugal. \\ ${ }^{2}$ Laboratório de Mastozoologia e Biogeografia, Departamento de Ciências Biológicas, Universidade Federal do Espírito Santo. \\ Avenida Marechal Campos 1468, Maruípe, 29043-900 Vitória, Espírito Santo, Brazil. \\ ${ }^{3}$ Corresponding author. E-mail: rgrocha@ua.pt
}

\begin{abstract}
We collected and analyzed 286 Barn owl, Tyto alba (Scopoli, 1769), pellets from two nests in different environments along the mid-Araguaia River in central Brazil. Our analyses revealed that these owls feed mainly on small mammals, especially rodents. Owls from the riverbanks at Fazenda Santa Fé had a more diverse diet, preying mainly on rodents that typically inhabit riparian grasslands - Holochilus sciureus Wagner, 1842 - and forests - Hylaeamys megacephalus (Fischer, 1814) and Oecomys spp., which probably also occur in forest borders or clearings. On the other hand, owls from an agroecosystem at Fazenda Lago Verde preyed mostly on rodent species common in these agrarian fields, Calomys tocantinsi Bonvicino, Lima \& Almeida, 2003. Additionally, we compared small mammal richness estimates based on the analysis of owl pellets with estimates from live-trapping in the same areas. Owl pellets revealed two rodent species undetected by live traps - Euryoryzomys sp. and Rattus rattus (Linnaeus, 1758) - and four rodent species were trapped, but not found in owl pellets - Oecomys roberti Thomas, 1904, Pseudoryzomys simplex (Winge, 1887), Rhipidomys ipukensis Rocha, B.M.A. Costa \& L.P. Costa, 2011, and Makalata didelphoides (Desmarest, 1817). Traps yielded higher species richness, but these two methods complement each other for surveying small rodents.
\end{abstract}

KEY WORDS. Agroecosystems; pellets; riverbanks; Rodentia.

The Barn owl, Tyto alba (Scopoli, 1769), is a nearly cosmopolitan owl that inhabits mostly open areas, including farms, grasslands and woods (MiкKola 1995, Sick 1997, Venable 1997). Owls are specialized predators and have very large eyes, which allow vision in limited light, and an acute hearing. These characteristics make them well adapted for hunting at night (VENABLE 1997). Although small mammals are the main food source of Barn owls, they also prey on other vertebrates and insects (e.g., JAKSIC et al. 1982, TAYLOR 1994, BELLOCQ 2000). Owls regurgitate prey remains in the form of pellets, which have been studied not only to understand their feeding habits (e.g., BeLLoce 1990, Scheibler \& Christoff 2004, Trejo \& Lambertucci 2007), but also as a method for inventorying small mammals (e.g., Bonvicino \& Bezerra 2003, Torre et al. 2004, Souza et al. 2010, Teta et al. 2010).

When compared with the 142 studies of Barn Owl pellets in Argentina (reviewed by Pardiñas \& Cirignoli 2002), very few studies were focused on this subject in Brazil (e.g. Escarlate-Tavares \& Pessôa 2005, Roda 2006, Scheibler \& Christoff 2004, 2007, Bueno \& Motta-Júnior 2008, Souza et al. 2010), and only three were carried out in central Brazil (MOTTA-JúNIOR \& TALAMONI 1996, JORDÃO et al. 1997, BONVICINO \& BEZERRA 2003). The aims of this study are: 1) to compare the species composition of small mammals consumed by Barn owls in two different environments within an ecotonal region between Cerrado and Amazonia, in central Bra- zil, and 2) to compare the estimates of small mammal richness obtained from these pellets with a concomitant small mammal inventory using live-traps in the same areas.

\section{MATERIAL AND METHODS}

This research took place in two different environments, about $140 \mathrm{~km}$ apart, in the mid-Araguaia River region of central Brazil. Fazenda Santa Fé (FSF), municipality of Santana do Araguaia, state of Pará, is a 65,000 ha private ranch, managed for cattle ranching, with about $65 \%$ of its area still covered with semi-deciduous forest. The forested area is concentrated near the riverbank. The nest from FSF was found inside an abandoned house in a large clearing that separates the forested area from the riverbank (Fig. 1). Fazenda Lago Verde (FLV), municipality of Lagoa da Confusão, state of Tocantins, is an 8,000 ha private ranch managed for artificially irrigated crop production (rice, maize, bean and soybean). About $70 \%$ of its area consists of pristine Cerrado sensu lato physiognomies, ranging from "cerradão" (dense savanna woodland), to open scrublands and grasslands (Oliveira-Filho \& Ratter 2002). Natural forest fragments, locally named "ipucas", occur within the agricultural (Fig. 2) and Cerrado matrices (MarTins et al. 2002). The nest from FLV was found inside an active barn. 

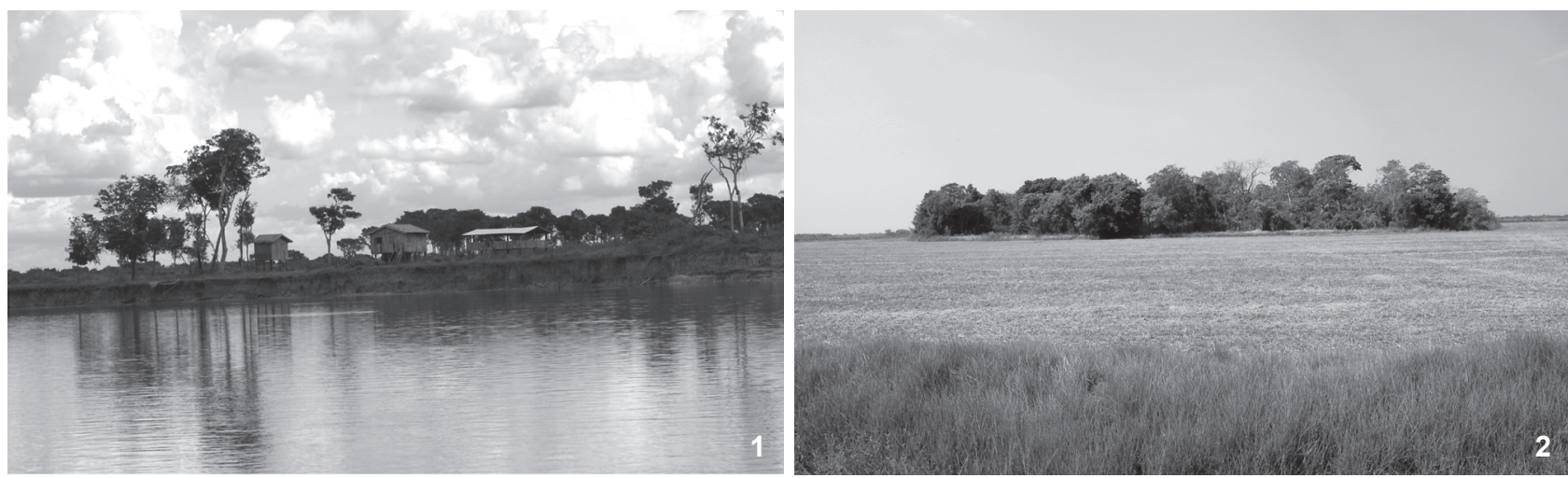

Figures 1-2. Landscape at the study area in the mid-Araguaia River in central Brazil: (1) abandoned house on the western riverbank at Fazenda Santa Fé; (2) "ipuca" surrounded by a cultivated area at Fazenda Lago Verde.

During September and November 2007, we collected 151 pellets and several pellet debris from the nest at FSF, which was occupied by an adult couple. In September 2008, we collected 135 pellets and several pellet debris from the nest at FLV, which was occupied by an adult couple and five owlets. Between June 2007 and November 2008, we conducted a live-trapping survey in the same areas along the mid-Araguaia River (Rосна et al. 2011). Ten sampling points were established mainly within forested areas along the mid-Araguaia riverbanks, four of which were established at FSF. Three sampling points were established at FLV in "ipucas". Each sampling point was sampled during three periods, averaging seven days each. Each sampling point consisted of a transect of sixteen $30 \mathrm{~L}$ pitfalls with drift fences; a transect with ten $60 \mathrm{~L}$ pitfalls with drift fences (except at FLV, where burying large pitfalls in waterlogged soil was unfeasible); a mixed transect with 22 Sherman traps $(45 \times 12.5 \times 14.5 \mathrm{~cm})$ and ten Tomahawk traps $(45 \times 21 \times 21 \mathrm{~cm})$ placed on the ground; and a mixed transect with four Sherman traps and four Tomahawk traps placed in the understory. Four additional transects with 22 Sherman and ten Tomahawk traps were established near irrigation channels and in the Cerrado sensu strictu matrix at FLV, which were sampled only during one seven-night period.

Following the protocol of YALDEN \& MORRIS (1990), each pellet was soaked individually in water and sorted to isolate bones and other prey remains. The number of prey per pellet was estimated as the minimum unequivocal number of individuals, based on the presence of unique structures, skulls and pairs of mandibles. Small mammals were identified based on cranial structures described in the literature (Voss 1991, Voss \& Carleton 1993, Musser et al. 1998, Patton et al. 2000, Bonvicino et al. 2003, WeKsler 2006, WeKsler et al. 2006), and by direct comparison to voucher specimens collected in the same area (Rocha et al. 2011), and deposited at the Coleção de Mamíferos of the Universidade Federal do Espírito Santo, Vitória, Brazil (UFES). Mammal specimens found in pellets have also been deposited in this collection. Amphibian and lizard remains were identified by comparison with vouchers specimens previously collected in the study area. Sigmodontine rodents were classified into five toothwear age classes (TWC1 through TWC5) as defined by Voss (1991). Toothwear age classes from 1 to 2 were considered juveniles, and from 3 to 5 were considered adults. We calculated the percentage of total number of prey and estimated prey biomass per species in the Barn Owl diet. The latter was calculated as the product of the number of prey (adult and juvenile) times the mean body weight of each species. All adult and juvenile body weights were obtained from specimens collected by RGR and EF in the study area, with the exception of Rattus rattus (Linnaeus, 1758), obtained from SCHeibler \& CHristoff (2004), and Euryoryzomys sp., obtained from Musser et al. (1998). Body weights of unidentified individuals were roughly estimated based on bone sizes.

Small mammal individuals were pooled together by species, study area (FSF or FLV), and sampling point, in the case of live-trapping; or groups of ten pellets, in the case of pellet sampling. Unidentified rodents found in pellets were excluded from subsequent analyses. Echimyid rodents and didelphid marsupials were included in live-trapping analyses, since individuals from both families were captured using this method. Rarefaction curves were generated with EstimateS 8.2.0 software for Mac (Colwell 2006), using the Mao Tau estimator (Colwell et al. 2004). This estimator was used for the calculation of the expected species richness values, their standard deviation and 95\% confidence intervals. Because datasets differ in the mean number of individuals per sample, rarefaction curves were scaled by individuals a posteriori, as suggested by Gotelu \& Colwell (2001). Shannon's H diversity index was estimated using EstimateS for each point of the rarefaction curves, following MAGURRAN (2004). Abundance-based (Chao 1 and ACE) and incidence-based (Chao 2 and ICE) species richness estimators were also calculated using EstimateS. Buzas and Gibson's E eveness index (BUZAS \& GIBSON 1969) was estimated according to HAYEK \& BUZAS (1997) using the equation, $\mathrm{E}=\mathrm{e}^{\mathrm{H}} / \mathrm{S}$, where $\mathrm{H}$ is the 
Shannon's information index (previously estimated) and $\mathrm{S}$ is the expected (Mao Tau estimator) species richness for the last point of the rarefaction curves.

\section{RESULTS}

A total of 286 pellets were analyzed from FSF and FLV. Two hundred twenty five vertebrate prey individuals were recorded in the pellets and debris from the FSF nest, which are represented mainly by rodents $(91.6 \%)$, followed by marsupials (5.8\%), amphibians (1.2\%), reptiles $(0.9 \%)$ and birds $(0.4 \%)$ (Tab. I). Remains of unidentified insects, mainly coleopterans, were recorded in 32 pellets, but they were excluded from our analyses, because we could not estimate the number of individuals. Although 36 rodent individuals remain unidentified due to severe damages in skulls and/or mandibles, we were able to identify seven rodent species belonging to Sigmodontinae. Calomys tocantinsi Bonvicino, Lima \& Almeida, 2003 (Fig. 8), Holochilus sciureus Wagner, 1842 (Fig. 9), Hylaeamys megacephalus (Fischer,
1814) (Fig. 7), Oligoryzomys fornesi (Massoia, 1973) (Fig. 3) and Oecomys paricola (Thomas, 1904) were unambiguously identified to the species level, and Euryoryzomys sp. (Fig. 5) and Oecomys sp. (Fig. 4) were identified to genus. The long and slit-like incisive foramen that is characteristic of Euryoryzomys was found in two of the analyzed skulls. However, due to skull damage, we could not confirm its carotid circulation pattern, which is an important diagnostic characteristic (MUSSER et al. 1998, WeKSLER et al. 2006). Individuals of Oecomys sp. were not assigned to any described species because two of the three sympatric species in this region are quite similar and also present high levels of intraspecific morphological variation (see Rocн et al. 2011). Three species of amphibians, Rhinella schneideri (Werner, 1894), Hypsiboas raniceps Cope, 1862 and Leptodactylus latrans (Steffen, 1815), and one reptile species, Ameiva ameiva (Linnaeus, 1758) were also unambiguously identified. Marsupials and birds were not identified, since complete skulls were missing from the pellets. Holochilus sciureus was the most consumed (37.8\%) and important species in terms of ingested biomass (70.9\%) by Barn

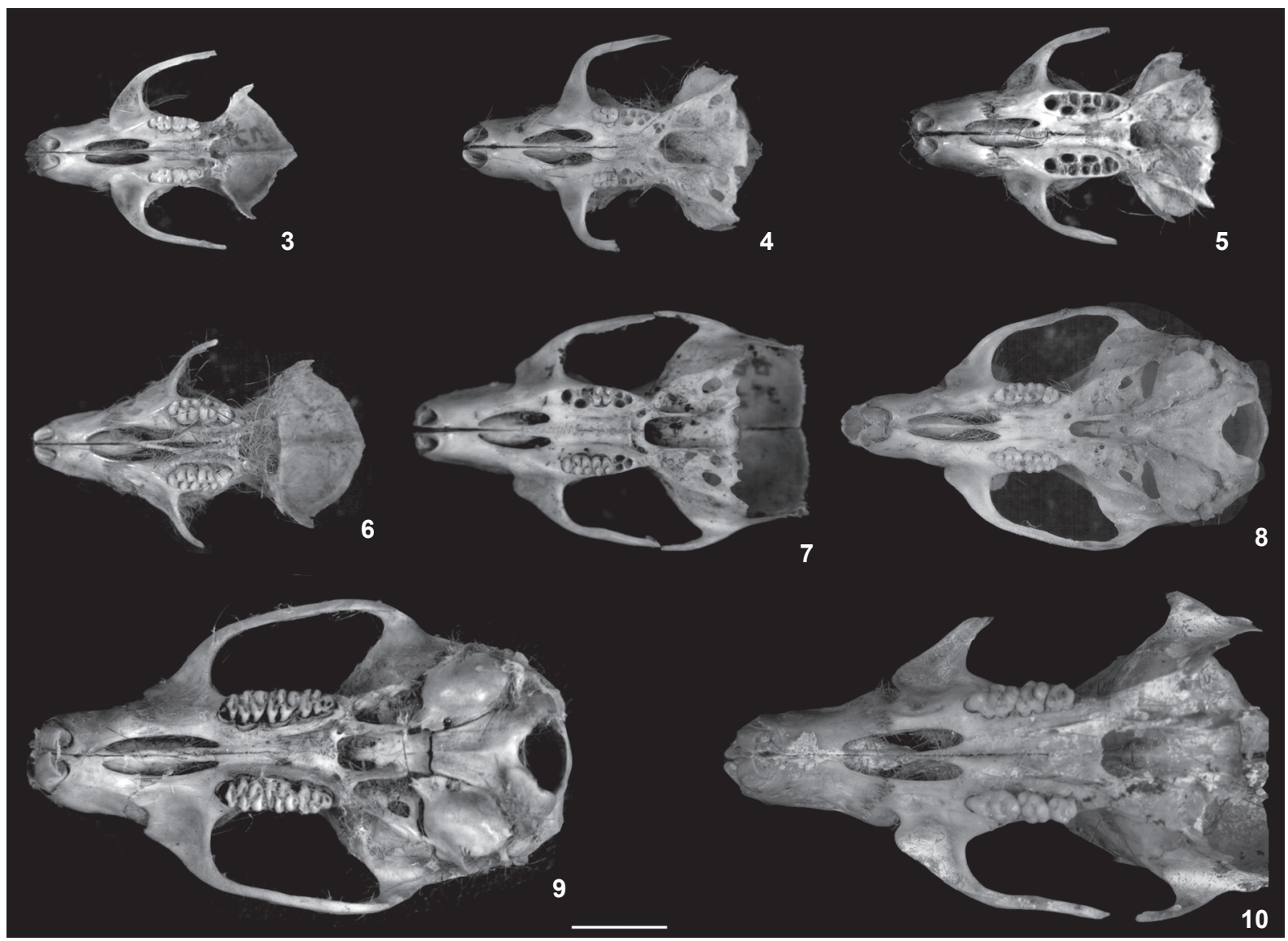

Figures 3-10. Ventral views of rodent skulls recovered from Barn Owl pellets: (3) Oligoryzomys fornesi; (4) Oecomys sp.; (5) Euryoryzomys sp.; (6) Necromys lasiurus; (7) Hylaeamys megacephalus; (8) Calomys tocantinsi; (9) Holochilus sciureus; (10) Rattus rattus. Scale bar = 5 mm. 
Table I. Number of adult and juvenile individuals, percentage of total number of prey (\%), and prey biomass (BM) in the Barn Owl pellets from Fazenda Santa Fé and Fazenda Lago Verde, along the mid-Araguaia River in central Brazil. Mean weight (recorded for adults and juveniles) and biomass are given in grams.

\begin{tabular}{|c|c|c|c|c|c|c|c|c|c|}
\hline \multirow{2}{*}{ Species } & \multirow{2}{*}{$\begin{array}{l}\text { Adult/juvenile } \\
\text { weight }\end{array}$} & \multicolumn{4}{|c|}{ Fazenda Santa Fé } & \multicolumn{4}{|c|}{ Fazenda Lago Verde } \\
\hline & & Adults & Juveniles & Total (\%) & BM (\%) & Adults & Juveniles & Total (\%) & BM (\%) \\
\hline \multicolumn{10}{|l|}{ Rodentia } \\
\hline Calomys tocantinsi & $36 / 24$ & 11 & 9 & $20(8.9)$ & $612(4.4)$ & 49 & 52 & $101(68.2)$ & $3012(53.5)$ \\
\hline Euryoryzomys sp. & $69 /-$ & 2 & - & $2(0.9)$ & $138(1.0)$ & - & - & - & - \\
\hline Holochilus sciureus & $167 / 68$ & 41 & 44 & $85(37.8)$ & $9837(70.9)$ & 10 & 4 & $14(9.5)$ & $1942(34.5)$ \\
\hline Hylaeamys megacephalus & $44 / 17$ & 27 & 2 & $29(12.9)$ & $1222(8.8)$ & - & - & - & - \\
\hline Necromys lasiurus & $30 / 20$ & - & - & - & - & 1 & 2 & $3(2.0)$ & $70(1.2)$ \\
\hline Oecomys paricola & $34 /-$ & 1 & - & $1(0.4)$ & $34(0.2)$ & - & - & - & - \\
\hline Oecomys sp. & $45 / 17$ & 10 & 3 & $13(5.8)$ & $501(3.6)$ & - & - & - & - \\
\hline Oligoryzomys fornesi & $17 / 10$ & 19 & 1 & $20(8.9)$ & $333(2.4)$ & 5 & 1 & $6(4.1)$ & $95(1.7)$ \\
\hline Rattus rattus & $92 /-$ & - & - & - & - & 2 & - & $2(1.4)$ & $184(3.2)$ \\
\hline Unidentified & $-/ 15$ & - & 36 & $36(16.0)$ & $540(3.9)$ & - & 22 & $22(14.9)$ & $330(5.9)$ \\
\hline Marsupialia & $23 /-$ & 13 & - & $13(5.8)$ & $299(2.2)$ & - & - & - & - \\
\hline Aves & & 1 & - & $1(0.4)$ & - & - & - & - & - \\
\hline \multicolumn{10}{|l|}{ Amphibia } \\
\hline Rhinella schneideri & $309 /-$ & 1 & - & $1(0.4)$ & $309(2.2)$ & - & - & - & - \\
\hline Hypsiboas raniceps & $8 /-$ & 1 & - & $1(0.4)$ & $8(0.1)$ & - & - & - & - \\
\hline Leptodactylus latrans & $11 /-$ & 1 & - & $1(0.4)$ & $11(0.1)$ & - & - & - & - \\
\hline \multicolumn{10}{|l|}{ Reptilia } \\
\hline Ameiva ameiva & $-/ 12$ & - & 2 & $2(0.9)$ & $24(0.2)$ & - & - & - & - \\
\hline Total & & 128 & 97 & $225(100)$ & $13868(100)$ & 67 & 81 & $148(100)$ & $5633(100)$ \\
\hline
\end{tabular}

Owl at FSF, followed by H. megacephalus $(12.9 \%$ and $8.8 \%$, respectively) and C. tocantinsi ( $8.9 \%$ and $4.4 \%$, respectively). Although only one individual of $R$. schneideri was consumed, it represented 2.2\% in terms of ingested biomass. Barn owls at FSF preyed relatively more on adults than juveniles (Tab. I).

The 148 vertebrate prey individuals recorded in the pellets and debris of the FLV nest were represented only by rodents. Unidentified insect remains were also recorded in six pellets, but as explained above they were also excluded from our analysis. Five rodent species were identified and $14.9 \%$ of the individuals remained unidentified (Tab. I). Out of these five rodent species, two are different from the FSF records, Necromys lasiurus (Lund, 1840) (Fig. 6) and R. rattus (Fig. 10), which were unambiguously identified. Calomys tocantinsi was the most consumed (68.2\%) and important species in terms of ingested biomass $(53.5 \%)$ by Barn owls at FLV, followed by $H$. sciureus (9.5\% and $34.5 \%$, respectively). Although only two individuals of $R$. rattus were consumed (1.4\%), they represented $3.2 \%$ in terms of ingested biomass. Barn owls at FLV preyed more on juveniles than adults (Tab. I).

An effort of 13,860 and 4,424 trap-nights yielded 180 captures at the mid-Araguaia riverbanks, including FSF, and 116 captures at FLV, representing 14 and 12 species of small mam- mals in each area (Tab. II), respectively. Rarefaction results show that species richness starts to accumulate faster (FSF), or at the same pace (FLV) in pellets than in live-traps (Figs 11 and 12). However, after including all sampled individuals, species richness was significantly higher in traps than in owl pellets, both at FSF and FLV. In both areas, the increase in species richness stabilizes much earlier in pellet sampling than in trap sampling, where species richness continues to increase until the end of the rarefaction curve (Figs 11 and 12). Confidence intervals converge towards the observed species richness estimate only in owl pellets from FLV (Fig. 12). In most cases, species richness estimators provided higher number of species than the observed species richness for both live traps and owl pellets (Tab. III). Diversity estimates from live traps were higher than from owl pellets in both areas, while evenness was higher for pellets than traps at FSF, the reverse occurred at FLV (Tab. III).

\section{DISCUSSION}

\section{Small mammals in the Barn Owl diet}

The ecological success of Barn owls is due to the great plasticity of their feeding habits (e.g., SCHeibler \& Christoff 2004, Leveau et al. 2006, Trejo \& Lambertucci 2007). In this study, Barn 

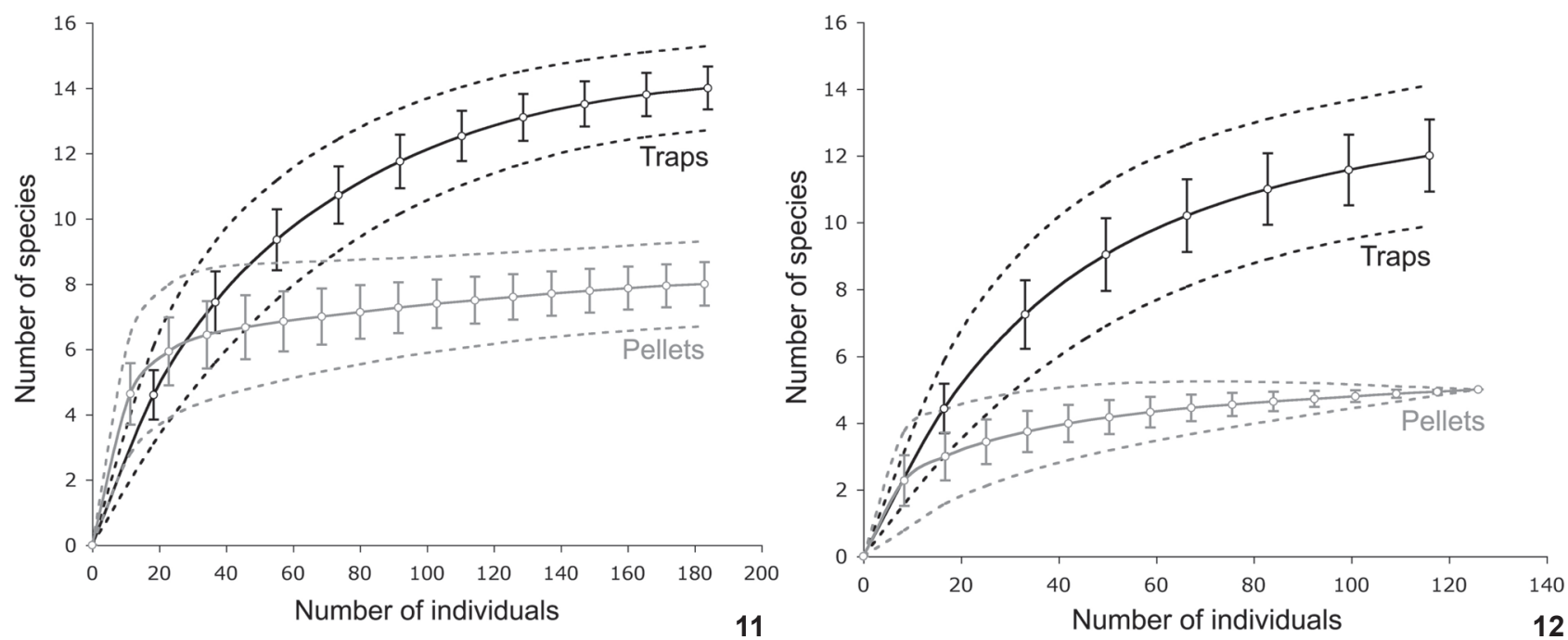

Figures 11-12. Species rarefaction curves (scaled by individuals) for trap and pellet sampling at each location sampled: (11) Fazenda Santa Fé; (12) Fazenda Lago Verde. Solid lines: expected species richness (Mao Tau estimator); dashed lines: 95\% confidence intervals; bars: standard deviation.

Table II. Number of adult and juvenile small mammals trapped at Fazenda Santa Fé and Fazenda Lago Verde, along the mid-Araguaia River in central Brazil.

\begin{tabular}{|c|c|c|c|c|c|c|c|}
\hline \multirow{2}{*}{ Species } & \multicolumn{3}{|c|}{ Fazenda Santa Fé } & \multicolumn{4}{|c|}{ Fazenda Lago Verde } \\
\hline & Adults & Juveniles & Total & & Adults & Juveniles & Total \\
\hline \multicolumn{8}{|l|}{ Rodentia } \\
\hline Calomys tocantinsi & 4 & - & 4 & & 12 & 6 & 18 \\
\hline Holochilus sciurus & - & - & - & & 2 & 1 & 3 \\
\hline Hylaeamys megacephalus & 9 & 8 & 17 & & 6 & - & 6 \\
\hline Necromys lasiurus & - & - & - & & 4 & 1 & 5 \\
\hline Oecomys roberti & 5 & - & 5 & & - & - & - \\
\hline Oecomys sp. & 42 & 17 & 59 & & 6 & 1 & 7 \\
\hline Oligoryzomys fornesi & 2 & 1 & 3 & & 6 & 1 & 7 \\
\hline Pseudoryzomys simplex & 1 & - & 1 & & 1 & - & 1 \\
\hline Rhipidomys ipukensis & - & - & - & & 22 & - & 22 \\
\hline Makalata didelphoides & 4 & - & 4 & & 2 & 1 & 3 \\
\hline \multicolumn{8}{|l|}{ Marsupialia } \\
\hline Caluromys philander (Linnaeus, 1758) & 3 & - & 3 & & - & - & - \\
\hline Didelphis albiventris & 7 & 4 & 11 & & 1 & - & 1 \\
\hline Didelphis marsupialis Linnaeus, 1758 & 47 & 4 & 51 & - & & - & - \\
\hline Gracilinanus agilis (Burmeister, 1854) & - & - & - & & 39 & 1 & 40 \\
\hline Marmosa murina (Linnaeus, 1758) & 9 & - & 9 & & - & - & - \\
\hline Metachirus nudicaudatus (É. Geoffroy St.-Hilaire, 1803) & 1 & - & 1 & & - & - & - \\
\hline Micoureus demerarae (O. Thomas, 1905) & 6 & - & 6 & & - & - & - \\
\hline Philander opossum & 6 & - & 6 & & 3 & - & 3 \\
\hline Total & 146 & 34 & 180 & & 104 & 12 & 116 \\
\hline
\end{tabular}


Table III. Species richness, abundance and incidence-based richness estimators, diversity and evenness indices for live-trap and pellet sampling in Fazenda Santa Fé (FSF) and Fazenda Lago Verde (FLV).

\begin{tabular}{llcccccc}
\hline & & \multicolumn{2}{c}{ FSF } & & \multicolumn{2}{c}{ FLV } \\
\cline { 3 - 4 } \cline { 7 - 8 } & & Pellets & Traps & & Pellets & Traps \\
\hline Species Richness & Sobs & 8 & 14 & & 5 & 12 \\
\hline Richness estimators & & & & & \\
\multirow{2}{*}{ Abundance } & Chao 1 & 8.50 & 15.00 & & 5.00 & 13.00 \\
& ACE & 9.00 & 14.92 & & 5.00 & 12.85 \\
\hline \multirow{2}{*}{ Incidence } & Chao 2 & 8.50 & 14.18 & & 5.00 & 12.64 \\
& ICE & 9.14 & 15.08 & & 5.71 & 13.61 \\
\hline Diversity & $\mathrm{H}$ & 1.59 & 1.97 & & 0.72 & 1.96 \\
\hline Equitability & $\mathrm{E}$ & 0.61 & 0.51 & & 0.41 & 0.59 \\
\hline
\end{tabular}

owls from FSF and FLV preyed on different species and different proportions, which may be related with differences in species assemblages from both areas. The nest at FSF is surrounded mainly by forested areas, with very little human occupation along the riverbanks, while the nest at FLV is located inside an active barn, surrounded by an agroecosystem.

The diet of the Barn Owl at FSF is more diverse, not only including non-volant small mammals that inhabit both open and forested areas, but also amphibians, reptiles, birds and insects. The main prey, $H$. sciureus, is a semi-aquatic rodent, which is probably hunted along riverbanks and in open areas. SCHEIBLER \& CHRISTOFF (2007) suggested that Barn owls are likely to concentrate their hunting effort in small marshes, which is also one of the plausible explanations for hunting on amphibians too. However, the amphibian species preyed in this area are also found in anthropogenic environments, as frequently observed by us. Hylaeamys megacephalus, C. tocantinsi and O. fornesi are terrestrial rodents that can be found in both open and forested areas (Bonvicino et al. 2008). However, it is noteworthy that the Barn Owl at FSF also hunted forest-dwelling mammals, such as the Euryoryzomys and Oecomys rodents (Bonvicino et al. 2008), which were probably hunted in forest borders or clearings.

More than half of the Barn Owl's diet at FLV is constituted by only one rodent species, $C$. tocantinsi, which is reflected in the low values of diversity and evenness obtained using pellet data from this area. This rodent was mainly trapped in open areas near crop fields at FLV, along with O. fornesi (Rocha et al. 2011). Necromys lasiurus is also common in grain storage locations and agrarian habitats (SCHEIBLER \& Christoff 2004). Rattus rattus is an exotic invasive species, commonly found near and inside human housing (Bonvicino et al. 2008). These observations at FLV clearly reinforce the statement of SCHEIBLER \& CHRISTOFF (2004), in which the diet of Barn Owl at agroecosystems reflects the human impact on its habitat, since this owl is mainly feeding on species that inhabits anthropogenic environments sur- rounding the nest. Additionally, Barn owls at FLV preyed more on juveniles than adults. The selection of smaller and younger individuals has been reported in southeastern Brazil (e.g., SCheibler \& Christoff 2004, Bueno \& MotTa-Júnior 2008). This tendency agrees with the ecological prediction of an active predator, which is more likely to feed on patchily distributed or sedentary prey (Grant \& NoAKEs 1987), such as juveniles in a nest.

Differences in prey selection by Barn owls as a function of species consumed or body mass have been discussed in several studies (e.g., Scheibler \& Christoff 2004, Leveau et al. 2006, Bueno \& MotTa-Júnior 2008). In this study, it is apparently more profitable for Barn owls at FSF to prey larger-sized sigmodontine rodents found near riverbanks. Conversely, there is a high incidence of smaller-sized sigmodontine rodents in crop fields, and Barn owls preyed heavily on them at FLV.

\section{Small mammal richness in pellets}

Barn Owl pellets have been used as a complementary method for inventorying small mammals (e.g., Bonvicino \& Bezerra 2003, Scheibler \& Christoff 2007, Souza et al. 2010). Our results revealed that pellets yielded a higher number of small mammal individuals, despite the relatively low number of pellets, when compared with the extensive live-trap effort along the Araguaia riverbanks and at FLV. Although traps yielded higher species richness than pellets, the species assemblages resulting from these methods are complementary, especially considering that live traps were set mainly in forested areas, while Barn owls hunt primarily in open areas and forest borders.

The presence of Euryoryzomys sp. in pellets from FSF represents the first record of this genus in this region of central Brazil, which is within the ranges of three species: E. emmonsae from Pará, E. lamia from Goiás, and E. nitidus from Mato Grosso (Bonvicino et al. 2008). Holochilus sciureus was never captured in traps at FSF, which reflects the semi-aquatic habitat specificity of this species. The exotic species $R$. rattus was also not collected in traps at FLV, despite its known occurrence in anthropogenic and disturbed areas of many biomes in Brazil (Bonvicino et al. 2008). On the other hand, larger species, such as the marsupials Didelphis albiventris Lund, 1840 and Philander opossum (Linnaeus, 1758) were absent from pellets despite their known occurrence in the study area, probably because of their size. Bonvicino \& Bezerra (2003) suggested that live traps appear to work better for surveying relatively larger small mammals, while pellets furnish species normally absent in trap sampling, probably due to adaptations to special microhabitats. Although some studies have registered larger small mammals in Barn Owl pellets (e.g., Souza et al. 2010), and large-sized $H$. sciureus was abundant in pellets from our study, there are limits in the size of the prey that these owls are able to capture (Mikolla 1995).

Owl pellet collections substantially increased the number of specimens of small mammals reported from the study area, and added two undetected genera (Euryoryzomys and Rattus) to 
the previous list of 22 small mammals (RocHa et al. 2011). On the other hand, four rodent species were trapped, but not found in owl pellets: Pseudoryzomys simplex (Winge, 1887), Oecomys roberti Thomas, 1904, Rhipidomys ipukensis Rocha, B.M.A. Costa \& L.P. Costa, 2011, and Makalata didelphoides (Desmarest, 1817). Considering its small size and preference for open habitats (Bonvicino et al. 2008), P. simplex is a suitable prey for Barn owls, but it may be uncommon in the region, given that only two specimens were trapped. Oecomys roberti is another suitable prey in terms of body size, but it prefers forested areas and was also uncommon in traps. Rhipidomys ipukensis is found mainly in "ipucas" (Rocha et al. 2011), which are natural forest fragments. Adult $M$. didelphoides are probably too large to be hunted, and this species is also arboreal and restrict to forested areas, occupying a different habitat than Barn owls. These results reflect relatively different trends in species diversity estimates using livetrapping and Owl pellet data. The results also highlight the efficiency of a natural predator, and its utility for inferring the composition of small mammal assemblages. Owl pellets are a valuable opportunistic resource, and should be combined with intensive live-trapping in various habitats, using different trap types for small mammal surveys. Beside the utility of Barn Owl pellet specimens in ecological studies, they also represent valuable material for systematic studies (PARDIÑAs et al. 2005) and a good source of DNA for genetic studies (TABerlet \& Fumagalli 1996). Therefore, Barn Owl pellets are especially useful in areas that still lack proper knowledge on their small mammal diversity, such as the Neotropics.

\section{ACKNOWLEDGMENTS}

We thank staff from Fazendas Santa Fé and Águas do Papagaio, Fazenda Lago Verde, and Ecotropical for all their logistic support. Fieldwork was performed using Federal (Instituto Chico Mendes de Conservação da Biodiversidade-ICMBio, permits 200/2006 and 14307-1) and State (Naturatins, permits: 019/2006 and 001/2008) conservation agency permits. RGR and EF were supported by two PhD grants from the Fundação Ciência e Tecnologia (Program POPHQREN, ref: SFRH/BD/ 24767/2005 and SFRH/BD/23191/2005, respectively). LPC and YLRL received grant and fellowship support from the Conselho Nacional de Desenvolvimento Científico e Tecnológico (CNPq, Brazil). We also thank three anonymous reviewers for their valuable comments on a previous version of this manuscript.

\section{LITERATURE CITED}

Belloce, M.I. 1990. Composicion y variacion temporal de la dieta de Tyto alba en ecosistemas agrarios pampeanos, Argentina. Vida Silvestre Neotropical 2 (2): 32-35.

Belloce, M.I. 2000. A review of the trophic ecology of the Barn Owl in Argentina. Journal of Raptor Research 34 (2): 108119.
Bonvicino, C.R. \& A.M.R. BEZERRA. 2003. Use of regurgitated pellets of Barn Owl (Tyto alba) for inventory small mammals in the Cerrado of central Brazil. Studies on Neotropical Fauna and Environment 38 (1): 1-5. doi: 0165-0521/03/3801.

Bonvicino, C.R.; J.F.S. Lima \& F.C. Almeida. 2003. A new species of Calomys Waterhouse (Rodentia, Sigmodontinae) from the Cerrado of Central Brazil. Revista Brasileira de Zoologia 20 (2): 301-307. doi: 10.1590/S0101-81752003000200021.

Bonvicino, C.R.; J.A. Oliveira \& P.S. D'Andrea. 2008. Guia dos roedores do Brasil, com chaves para géneros baseadas em caracteres externos. Rio de Janeiro, Centro Pan-Americano de Febre Aftosa, 120p.

Bueno, A.A. \& J.C. MotTa-Júnior. 2008. Small mammal prey selection by two Owl species in southeastern Brazil. Journal of Raptor Research 42 (4): 248-255. doi: 10.3356/JRR-07-37.1.

BuZAs, M.A. \& T.G. Gibson. 1969. Species diversity: benthonic foraminifera in western North Atlantic. Science 163:72-75. doi: 10.1126/science.163.3862.72.

ColWell, R.K. 2006. Biota: the diversity database manager. Sunderland, Sinauer Associates, version 2.

Colwell, R.K.; C.X. MaO \& J. Chang. 2004. Interpolating, extrapolating, and comparing incidence-based species accumulation curves. Ecology 85: 2717-2727. doi: 10.1890/ 03-0557.

Escarlate-Tavares, F. \& L.M. Pessôa. 2005. Bats (Chiroptera, Mammalia) in Barn Owl (Tyto alba) pellets in northern Pantanal, Mato Grosso, Brazil. Mastozoología Neotropical 12 (1): 61-67.

Gotelli, N.J. \& R.K. Colwell. 2001. Quantifying biodiversity: procedures and pitfalls in the measurement and comparison of species richness. Ecology Letters 4: 379-391. doi: 10.1046/ j.1461-0248.2001.00230.x.

Grant J.W.A. \& D.L.G. Noakes. 1987. Movers and stayers: foraging tactics of young-of-the-year Brook Charr, Salvelinus fontinalis. Journal of Animal Ecology 56: 1001-1013.

HAYEK, L.A.C. \& M.A. BuzAs. 1997. Surveying natural populations. New York, Columbia University Press, 448p.

Jaksic, F.M.; R.I. Seib \& C.M. Herrera. 1982. Predation by the Barn owl (Tyto alba) in Mediterranean habitats of Chile, Spain and California. The American Midland Naturalist 107: 151-162.

JoRdão, F.S.; M.L. ReIs \& D.S. LouZADA. 1997. Análise do conteúdo de pelotas de Tyto alba (Strigiformes, Tytonidae) na Estação Ecológica de Águas Emendadas (Brasília, DF), p. 207209. In: L.L. Leite \& C.H. SAITo (Eds). Contribuição ao conhecimento ecológico do Cerrado. Brasília, Universidade de Brasília, 326p.

Leveau, L.M.; P. Teta; R. Bogdaschewsky \& U.F.J. Pardiñas. 2006. Feeding habits of the Barn Owl (Tyto alba) along a longitudinal-latitudinal gradient in central Argentina. Ornitologia Neotropical 17 (3): 353-362.

MagurRan, A.E. 2004. Measuring biological diversity. Malden, Blackwell Publishing, 260p. 
Martins, I.C.M.; V.P. Soares; E. Silva \& R.S. Brites. 2002. Diagnóstico ambiental no contexto da paisagem de fragmentos florestais naturais "Ipucas" no município de Lagoa da Confusão, Tocantins. Revista Árvore 26 (3): 299-309. doi: 10.1590/S0100-67622002000300005.

MiккоLA, H. 1995. Rapaces Nocturnas de Europa. Lleida, Editorial Perfils, 448p.

Motta-Júnior, J.C. \& S.A. Talamoni. 1996. Biomassa de presas consumidas por Tyto alba (Strigiformes: Tytonidae) durante a estação reprodutiva no Distrito Federal. Ararajuba 4: 3841.

Musser, G.R.; M.D. Carleton; E.M. Brothers \& A.L. Gardner. 1998. Systematic studies of oryzomyine rodents (Muridae, Sigmodontinae): diagnosis and distributions of species formerly assigned to Oryzomys "capito". Bulletin of the American Museum of Natural History 236: 1-376.

Oliveira-Filho, A.T. \& J.A. Ratter. 2002. Vegetation physiognomies and woody flora of the Cerrado biome, p. 91-120. In: P.A. Oliveira \& R.J. MARQuis (Eds). The Cerrados of Brazil, ecology and natural history of a neotropical savanna. NewYork, Columbia University Press, 398p.

Patton, J.L.; M.N.F. da Silva \& J.R. Malcolm. 2000. Mammals of the Rio Juruá and the evolutionary and ecological diversification of Amazonia. Bulletin of the American Museum of Natural History 244: 1-306.

PARdiÑAS, U.F.J. \& S. Cirignoli. 2002. Bibliografía comentada sobre los análisis de egagrópilas de aves rapaces en Argentina. Ornitologia Neotropical 13 (1): 31-59.

Pardiñas, U.F.J.; G. D’Ellía; S. Cirignoli \& P. Suarez. 2005. A new species of Akodon (Rodentia, Cricetidae) from the northern Campos grasslands of Argentina. Journal of Mammalogy 86 (3): 462-474. doi: 10.1644/1545-1542(2005)86[462: ANSOAR]2.0.CO;2.

Rocha, R.G.; E. Ferreira; B.M.A. Oliveira; I.C.M. Martins; Y.L.R. Leite; L.P. Costa \& C. Fonseca. 2011. Small mammals of the mid-Araguaia river in Central Brazil, with the description of a new species of climbing rat. Zootaxa 2789: 1-34.

RodA, S.A. 2006. Dieta de Tyto alba na Estação Ecológica do Tapacurá, Pernambuco, Brasil. Revista Brasileira de Ornitologia 14 (4): 449-452.

Scheibler, D.R. \& A.U. Christoff. 2004. Small mammals in the diet of Barn Owls (Tyto alba) in agroecosystems of southern Brazil. Ornitologia Neotropical 15: 65-70.

SCheibler, D.R. \& A.U. Christoff. 2007. Habitat associations of small mammals in southern Brazil and use of regurgitated pellets of birds of prey for inventorying a local fauna. Brazilian Journal of Biology 67 (4): 619-625. doi: 10.1590/ S1519-69842007000400005.

SICK, H. 1997. Ornitologia Brasileira. Rio de Janeiro, Editora Nova Fronteira, 912p.

Souza, D.P.; P.H. Asfora; T.C. LiRa \& D. Astúa. 2010. Small mammals in Barn Owl (Tyto alba - Aves, Strigiformes) pellets from northeastern Brazil, with new records of Gracilinanus and Cryptonanus (Didelphimorphia, Didelphidae). Mammalian Biology 75 (4): 370-374. doi: 10.1016/j.mambio.2009.08.003.

Taberlet, P. \& L. Fumagalli. 1996. Owl pellets as a source of DNA for genetic studies of small mammals. Molecular Ecology 5: 301-305. doi: 10.1046/j.1365-294X.1996.00084.x.

TAYlOR, I. 1994. Barn owls. Predator-prey relationships and conservation. Cambridge, University Press, 324p.

Teta, P.; C.M. González-Fischer; M. Codesido \& D.N. Bilenca. 2010. A contribution from Barn Owl pellets analysis to known micromammalian distributions in Buenos Aires province, Argentina. Mammalia 74: 97-103. doi: 10.1515/MAMM.2009.069.

Torre, I.; A. Arrizabalaga \& C. Flaquer. 2004. Three methods for assessing richness and composition of small mammal communities. Journal of Mammalogy 85 (3): 524-530. doi: 10.1644/BJK-112

Trejo, A. \& S. Lambertucci. 2007. Feeding habits of Barn Owls along a vegetative gradient in northern Patagonia. Journal of Raptor Research 41 (4): 277-287. doi: 10.3356/08921016(2007)41[277:FHOBOA]2.0.CO;2.

Venable, N.J. 1997. Birds of Prey. Virginia, West Virginia University Extension Service, 52p.

Voss, R. S. 1991. An introduction to the neotropical muroid rodent genus Zygodontomys. Bulletin of the American Museum of Natural History 210: 1-113.

Voss, R.S. \& M.D. Carleton. 1993. A new genus for Hesperomys molitor Winge and Holochilus magnus Hershkovitz (Mammalia, Muridae) with an analysis of its phylogenetic relationships. American Museum Novitates 3085: 1-39.

WeksLer, M. 2006. Phylogenetic relationships of oryzomine rodents (Muroidea: Sigmodontinae): separate and combined analyses of morphological and molecular data. Bulletin of the American Museum of Natural History 296: 1-149.

Wersler, M.; A.R. Percequillo \& R.S. Voss. 2006. Ten new genera of oryzomyine rodents (Cricetidae: Sigmodontinae). American Museum Novitates 3537: 1-29.

Yalden, D.W. \& P.A. Morris. 1990. Owl Pellet Analysis. London, Occasional Publication 13, Mammal Society, 24p.

Submitted: 10.V.2011; Accepted: 02.XI.2011. Editorial responsibility: Fernando de C. Passos 